\title{
The acute-phase response in endometriosis of women
}

\author{
G. A. J. Dunselman, P. X. J. M. Bouckaert and J. L. H. Evers \\ Department of Obstetrics and Gynaecology, Maastricht University Hospital, PO Box 1918, \\ 6201 BX Maastricht, The Netherlands
}

\begin{abstract}
Summary. Peritoneal fluid volume was determined and concentrations of $\mathrm{C}$-reactive protein, $\alpha_{1}$-antitrypsin, acid- $\alpha_{1}$-glycoprotein, $\alpha_{2}$-macroglobulin, haptoglobin, complement factors $\mathrm{C}_{3}$ and $\mathrm{C}_{4}, \mathrm{IgG}, \mathrm{IgA}$ and IgM were measured in the supernatant of the peritoneal fluid and in serum by means of a radial-immunodiffusion technique in 25 patients with and in 45 patients without endometriosis. Peritoneal fluid volume was not different between the two groups. The peritoneal fluid:serum ratios for the proteins determined showed a significant inverse correlation with their molecular weight in both groups, indicating that their presence in peritoneal fluid is governed by exudation according to their molecular weight, rather than by active production in, or selective release into, the peritoneal cavity. In control patients only, the ratios of most of the individual proteins studied were significantly higher in the luteal than in the follicular phase. We suggest that the high values of peritoneal fluid:serum ratios in endometriosis patients in the follicular phase reflects an additional contribution by endometriotic tissue and peritoneal macrophages. In the luteal phase, the cycle-dependent increase of protein exudation obscures this additional contribution.

We conclude that endometriosis does not cause marked intra-abdominal inflammatory changes. If the presence of endometriosis lowers fecundity, the mechanism probably does not involve acute-phase protein synthesis.
\end{abstract}

Keywords: endometriosis; acute-phase proteins; peritoneal fluid; man

\section{Introduction}

There is circumstantial evidence that a relationship exists between endometriosis, even in its milder forms, and subfertility, but the cause of this subfertility remains unclear. It has been suggested that in women with endometriosis there is an inflammatory reaction of the pelvic peritoneum (Drake $e t$ al., 1980; Haney et al., 1981; Halme et al., 1987; Fazleabas et al., 1987). This inflammatory reaction may lead to subfertility by causing changes in the peritoneal environment, in which follicular development, ovulation, fertilization and tubal transport takes place, analogous to the intrauterine inflammatory reaction present in users of intrauterine contraceptive devices, which lowers the probability of conception by similarly postulated mechanisms (Casslén \& Ohlsson, 1981). Inflammation, as a local response to tissue injury, results in changes in vascular calibre and flow, increased vascular permeability and attraction of leucocytes. Accordingly, an inflammatory reaction secondary to endometriosis may result in increased production of peritoneal fluid (Drake et al., 1980; Haney et al., 1981; Syrop \& Halme, 1987a), secretion of prostaglandins (PG) (Ylikorkala et al., 1984; DeLeon et al., 1986; Vernon et al., 1986) and protease inhibitors (Fazleabas et al., 1987) and attraction and differentiation of macrophages (Haney et al., 1981; Halme et al., 1987). Conflicting results have been reported on the influence of endometriosis on peritoneal fluid volume and the concentration of PGs. More agreement exists on the increased number and on the increased activation of intra-abdominal macrophages in patients with endometriosis (see Syrop \& Halme, $1987 \mathrm{~b}$ for review). 
Additionally a number of systemic and metabolic changes occur during the acute-phase of inflammation. The ultimate goal of the acute-phase response is the removal of damaged tissue and the repair of the affected organ (Kushner, 1982). In patients with pelvic inflammatory disease acutephase proteins were shown to be present in serum (Künzig et al., 1985). If endometriosis causes intraperitoneal inflammatory changes, this might be reflected in measures of the acute-phase response.

To delineate the extent of inflammatory changes secondary to the presence of endometriosis we determined, in addition to peritoneal fluid volume, various indicators of the acute-phase response.

\section{Materials and Methods}

Peritoneal fluid was collected during laparoscopy in 70 patients from the pouch of Douglas and the vesicouterine space under direct vision as described by Bouckaert et al. (1986a). The laparoscopies were planned in the early luteal phase of the menstrual cycle, based on information regarding the length of the previous cycles and the first day of the last menstrual period. The indication for laparoscopy was infertility in 40 patients, abdominal pain in 9 and sterilization in 21 . They all had regular cycles, ranging from 23 to 35 days. None of the patients had used oral contraceptives or ovulation-inducing drugs or an intrauterine contraceptive device for at least 3 months before the laparoscopy. Patients with occluded Fallopian tubes were excluded. At laparoscopy all patients were carefully screened for the presence of endometriosis. The diagnosis was made on morphological grounds. Endometriosis was identified according to the classification of the American Fertility Society (AFS) (1979).

After collection of the peritoneal fluid, the volume was measured, the fluid was centrifuged and the supernatant stored at $-70^{\circ} \mathrm{C}$ until assayed. Before induction of anaesthesia a $5-\mathrm{ml}$ blood sample was withdrawn, centrifuged and the supernatant stored at $-70^{\circ} \mathrm{C}$ until assayed. In serum and in the supernatant of the peritoneal fluid, oestradiol-17 $\beta$ and progesterone concentrations were determined. The values of oestradiol- $17 \beta$ and progesterone measured in serum and related to those in peritoneal fluid served to divide the cycle into two phases, i.e. the follicular and the luteal phase (Bouckaert et al., 1986b).

Concentrations of C-reactive protein, $\alpha_{1}$-antitrypsin, acid- $\alpha_{1}$-glycoprotein, $\alpha_{2}$-macroglobulin, haptoglobin, complement factors $\mathrm{C}_{3}$ and $\mathrm{C}_{4}, \operatorname{IgG}, \mathrm{IgA}$ and IgM were measured in the supernatant of the peritoneal fluid and in serum by means of a radial-immunodiffusion technique based on the radial diffusion and precipitation of a protein with its corresponding monospecfic antiserum in an agar gel layer (M-Partigen and LC-partigen immunodiffusion plates: Behring Institut, Amsterdam, The Netherlands) (Mancini et al., 1965). The interassay variabilities (\%) for the proteins that were analysed were 6.4 for C-reactive protein, 3.9 for $\alpha_{1}$-antitrypsin, 2.3 for acid- $\alpha_{1}$-glycoprotein, 7.5 for $\alpha_{2}$-macroglobulin, 4.3 for haptoglobin, 5.5 for $C_{3}$-protein, 4.6 for $C_{4}$-protein, 2.5 for $\operatorname{IgA}, 2 \cdot 3$ for $\operatorname{IgG}$, and 3.0 for IgM.

The ratio of peritoneal fluid concentration/serum concentration ( $p / s$ ratio) was determined for the individual proteins. Peritoneal fluid volume and the $\mathrm{p} / \mathrm{s}$ ratios were compared between patients with and without endometriosis and between the follicular and the luteal phase of the cycle for patients with endometriosis and controls. The results were tested statistically by the Wilcoxon rank sum test for unpaired samples. Statistical significance was defined as $P<0.05$. Spearman's rank correlation test was applied to test the correlation between the $\mathrm{p} / \mathrm{s}$ ratio of the individual proteins and their molecular weight.

\section{Results}

At laparoscopy endometriosis was diagnosed in 25 patients (AFS score 1, N = 16; AFS score 2, $\mathrm{N}=9$ ). The controls were 45 patients without the disease. Based on the information from serum and peritoneal fluid determinations of oestradiol-17 $\beta$ and progesterone, 6 patients in the endometriosis group were classified in the follicular and 19 in the luteal phase of the cycle. The figures for controls were 4 and 41 respectively.

C-reactive protein was below the level of detection $(5 \mathrm{mg} / \mathrm{l})$ in peritoneal fluid and serum in all patients studied.

In patients with endometriosis there was an increase of the peritoneal fluid volume in the luteal phase of the cycle (Table $1 ; P=0 \cdot 051$ ). No significant differences were noted between patients with and without endometriosis for the ratio of individual proteins in peritoneal fluid and serum (Table 2). Values for these ratios in the follicular and luteal phase of the cycle are shown in Table 3 . In patients with endometriosis only the IgG value differed significantly between the two phases of the cycle, but in the controls all the values except those for $\alpha_{1}$-antitrypsin, IgG and IgM were increased in the luteal phase of the cycle. 
Table 1. Peritoneal fluid volume ( $\mathrm{ml})$ in the follicular, the luteal phase and the cycle as a whole in endometriosis and control patients

\begin{tabular}{lccccccc}
\hline & \multicolumn{3}{c}{ Endometriosis patients } & & \multicolumn{3}{c}{ Control patients } \\
\cline { 2 - 3 } \cline { 8 - 9 } & $\mathrm{N}$ & Median & Range & & $\mathrm{N}$ & Median & Range \\
\hline Follicular phase & 6 & $9 \cdot 5$ & $6-20$ & & 4 & 6.5 & $4-25$ \\
Luteal phase & 19 & $24^{*}$ & $5-42$ & & 41 & 12 & $3-70$ \\
Whole cycle & 25 & 18 & $5-42$ & & 45 & 12 & $3-70$ \\
\hline
\end{tabular}

${ }^{*} P=0.051$ compared with follicular phase.

Table 2. The ratios of various proteins in peritoneal fluid and serum in endometriosis and control patients

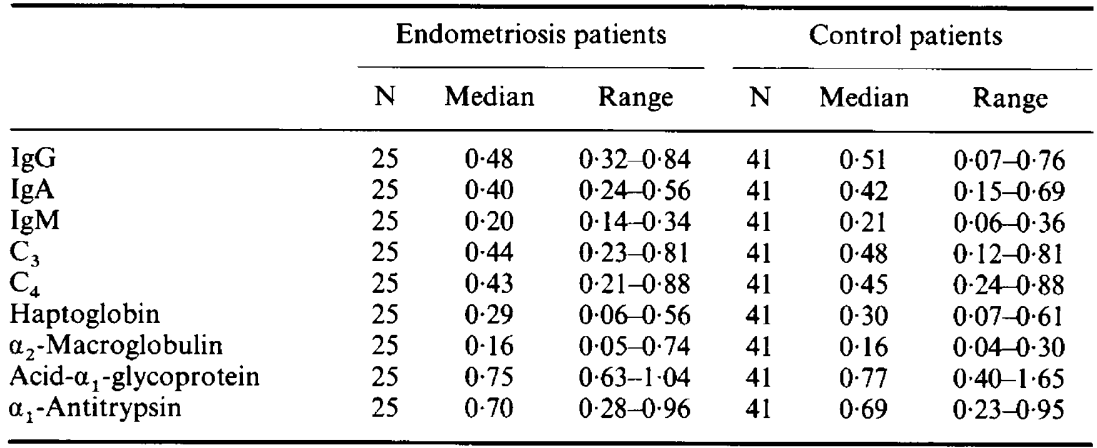

Table 3. The ratios of various proteins in the peritoneal fluid and serum of endometriosis and control patients in the follicular and luteal phases

\begin{tabular}{|c|c|c|c|c|c|c|c|c|c|c|c|c|}
\hline & \multicolumn{6}{|c|}{ Endometriosis patients } & \multicolumn{6}{|c|}{ Control patients } \\
\hline & \multicolumn{3}{|c|}{ Follicular phase } & \multicolumn{3}{|c|}{ Luteal phase } & \multicolumn{3}{|c|}{ Follicular phase } & \multicolumn{3}{|c|}{ Luteal phase } \\
\hline & $\mathbf{N}$ & Median & Range & $\mathbf{N}$ & Median & Range & $\mathrm{N}$ & Median & Range & $\mathbf{N}$ & Median & Range \\
\hline IgG & 6 & 0.43 & $\begin{array}{l}0.32- \\
0.51\end{array}$ & 19 & $0 \cdot 50^{*}$ & $\begin{array}{l}0.33 \\
0.84\end{array}$ & 4 & 0.43 & $\begin{array}{l}0.22- \\
0.50\end{array}$ & 37 & 0.52 & $\begin{array}{l}0.07- \\
0.76\end{array}$ \\
\hline IgA & 6 & $0 \cdot 39$ & $\begin{array}{l}0.24 \\
0.56\end{array}$ & 19 & 0.42 & $\begin{array}{l}0 \cdot 27- \\
0.54\end{array}$ & 4 & 0.34 & $\begin{array}{l}0 \cdot 15- \\
0 \cdot 40\end{array}$ & 37 & $0 \cdot 43^{*}$ & $\begin{array}{l}0.18- \\
0.69\end{array}$ \\
\hline IgM & 6 & $0 \cdot 26$ & $\begin{array}{l}0 \cdot 14 \\
0 \cdot 34\end{array}$ & 19 & $0 \cdot 19$ & $\begin{array}{l}0.15- \\
0.29\end{array}$ & 4 & $0 \cdot 18$ & $\begin{array}{l}0.07 \\
0.24\end{array}$ & 37 & $0 \cdot 21$ & $\begin{array}{l}0.06- \\
0.36\end{array}$ \\
\hline $\mathrm{C}_{3}$ & 6 & 0.41 & $\begin{array}{l}0 \cdot 23- \\
0.56\end{array}$ & 19 & 0.46 & $\begin{array}{l}0.30- \\
0.81\end{array}$ & 4 & $0 \cdot 32$ & $\begin{array}{l}0 \cdot 24 \\
0 \cdot 37\end{array}$ & 37 & $0.49 *$ & $\begin{array}{l}0 \cdot 12- \\
0.81\end{array}$ \\
\hline $\mathrm{C}_{4}$ & 6 & 0.39 & $\begin{array}{l}0 \cdot 23- \\
0.56\end{array}$ & 19 & 0.45 & $\begin{array}{l}0.21- \\
0.88\end{array}$ & 4 & $0 \cdot 33$ & $\begin{array}{l}0.24- \\
0.43\end{array}$ & 37 & $0 \cdot 50^{*}$ & $\begin{array}{l}0.26- \\
0.88\end{array}$ \\
\hline Haptoglobin & 6 & $0 \cdot 19$ & $\begin{array}{l}0.09 \\
0.50\end{array}$ & 19 & $0 \cdot 36$ & $\begin{array}{l}0.06- \\
0.56\end{array}$ & 4 & 0.09 & $\begin{array}{l}0 \cdot 07- \\
0 \cdot 36\end{array}$ & 37 & $0 \cdot 30^{*}$ & $\begin{array}{l}0.08- \\
0.61\end{array}$ \\
\hline$\alpha_{2}$-Macroglobulin & 6 & $0 \cdot 16$ & $\begin{array}{l}0.05- \\
0.25\end{array}$ & 19 & $0 \cdot 16$ & $\begin{array}{l}0.09 \\
0.74\end{array}$ & 4 & 0.07 & $\begin{array}{l}0.04 \\
0.16\end{array}$ & 37 & $0 \cdot 17^{*}$ & $\begin{array}{l}0 \cdot 05- \\
0 \cdot 30\end{array}$ \\
\hline $\begin{array}{l}\text { Acid- } \alpha_{1}- \\
\text { glycoprotein }\end{array}$ & 6 & 0.75 & $\begin{array}{l}0.72- \\
0.96\end{array}$ & 19 & 0.75 & $\begin{array}{l}0.63- \\
1.04\end{array}$ & 4 & 0.66 & $\begin{array}{l}0.47- \\
0.75\end{array}$ & 37 & $0 \cdot 79^{*}$ & $\begin{array}{l}0.40- \\
1.65\end{array}$ \\
\hline$\alpha_{1}$-Antitrypsin & 6 & $0 \cdot 64$ & $\begin{array}{l}0.53- \\
0.96\end{array}$ & 19 & 0.71 & $\begin{array}{l}0.28- \\
0.80\end{array}$ & 4 & 0.45 & $\begin{array}{l}0.23- \\
0.77\end{array}$ & 37 & $0 \cdot 70$ & $\begin{array}{l}0.24- \\
0 \cdot 95\end{array}$ \\
\hline
\end{tabular}

${ }^{*} P<0.05$, compared with follicular-phase value. 
Table 4. Molecular weight and the peritoneal fluid:serum ratio of the various proteins, arranged from low to high molecular weight, in endometriosis and control patients

\begin{tabular}{|c|c|c|c|}
\hline & $\begin{array}{l}\text { Molecular } \\
\text { weight }\end{array}$ & $\begin{array}{l}\text { Endometriosis } \\
\text { patients }\end{array}$ & $\begin{array}{l}\text { Control } \\
\text { patients }\end{array}$ \\
\hline Acid- $\alpha_{1}$-glycoprotein & 40000 & 0.75 & 0.77 \\
\hline$\alpha_{1}$-Antitrypsin & 54000 & 0.67 & 0.65 \\
\hline IgG & 160000 & 0.48 & 0.51 \\
\hline $\operatorname{Ig} A$ & 160000 & $0 \cdot 40$ & 0.42 \\
\hline $\mathrm{C}_{3}$ & 180000 & 0.44 & 0.48 \\
\hline $\mathrm{C}_{4}$ & 260000 & 0.43 & 0.45 \\
\hline Haptoglobin & 340000 & 0.29 & $0 \cdot 30$ \\
\hline$\alpha_{2}$-Macroglobulin & 725000 & $0 \cdot 16$ & $0 \cdot 16$ \\
\hline $\operatorname{IgM}$ & 900000 & $0 \cdot 20$ & $0 \cdot 21$ \\
\hline
\end{tabular}

Correlating the results of the peritoneal fluid:serum ratio for the individual proteins with their molecular weights a significant inverse relationship was found in the endometriosis patients $(\mathrm{N}=9, r=-0.93, P<0.01)$ and in the controls $(\mathrm{N}=9, r=-0.93, P<0.01)$ (Spearman's rank correlation test): the higher the molecular weight of a given protein, the lower was its concentration in the peritoneal fluid (Table 4).

\section{Discussion}

Peritoneal fluid is mainly the result of ovarian exudation, while peritoneal exudation, follicular rupture and tubal secretion contribute only a small volume (Maathuis et al., 1978; Koninckx et al., 1980; Bouckaert et al., 1986a). The supposed inflammatory reaction secondary to endometriosis may cause an increased permeability of the subperitoneal capillaries, resulting in a change of the equilibrium between in- and outflow of fluid across the peritoneal membrane, leading to an increased peritoneal fluid volume. Since we did not find such an increase, we suggest that the inflammatory reaction is not of such a degree that it gives rise to a significant change in peritoneal fluid volume. However, an increased production of peritoneal fluid could be counterbalanced by an increased reabsorption by the subperitoneal capillaries.

The acute-phase reaction, in which the concentration of certain plasma proteins increases, is recognized as a general and non-specific response to most forms of infective and noninfective inflammatory processes, cell and/or tissue necrosis, and malignant neoplasia. The acute-phase proteins are synthesized in the liver (Pepys, 1981).

Circulating proteins reach the peritoneal cavity by exudation. The concentration of the various proteins in the peritoneal fluid depends predominantly on the hydrostatic pressure in the ovarian capillary network, the diameter of the endothelial gaps, the electrical charge of the individual proteins and their molecular weight (Bouckaert et al., 1986a). In endometriosis patients the concentration of acute-phase proteins, complement factors and immunoglobulins in the abdominal cavity may be increased secondary to changes in vascular permeability. Additionally some of the acute-phase proteins and complement factors are secreted by macrophages in an advanced stage of differentiation (Nathan, 1987).

To detect possible differences in the acute-phase response in peritoneal fluid between endometriosis patients and controls, it seems appropriate, in view of the above, to consider the ratio of the concentrations of the separate proteins in peritoneal fluid and serum. This ratio reflects the various sources of the peritoneal fluid proteins, i.e. exudation or in-situ production. Our earlier finding (Bouckaert et al., 1986a) of a significant inverse relationship between the molecular weight 
of the specific protein and its peritoneal fluid:serum ratio was confirmed in the control group. A comparable relationship was found for endometriosis patients. Retrograde menstruation, ovulation and, in endometriosis patients, cyclic shedding of endometriotic implants cause a continuously changing intra-abdominal environment and thus possibly alter intra-abdominal protein concentrations. When ratios for the specific proteins were compared between endometriosis patients and controls no significant differences were found, indicating a constant and equal exudation and/or in-situ production of these proteins in both groups. Apparently the intra-abdominal protein concentration is not influenced to a great extent by the presence of endometriosis.

The ratios of the individual proteins in the follicular phase of the cycle in endometriosis patients in comparison to controls suggests a contribution from sources other than the ovaries, e.g. the peritoneum and the intra-abdominal macrophages, reflecting an intra-abdominal inflammatory reaction, secondary to endometriosis. The cycle-dependent increase of protein exudation in the luteal phase of the cycle may outweigh the presumptive contribution of the peritoneal exudation and production by macrophages in endometriosis patients. Due to the low sample size $(N=4)$ the ratios of the follicular phase of control patients could be erroneously low and thus indirectly give the impression of a high ratio in the follicular phase of the endometriosis patients.

We conclude that endometriosis does not cause marked intra-abdominal inflammatory changes. We base this on the lack of a significant increase of the peritoneal fluid volume and of the peritoneal fluid:serum ratios of the various proteins determined in patients with endometriosis compared to controls. If the presence of endometriosis lowers fecundity, the mechanism probably does not involve acute-phase protein synthesis.

The work presented in this paper was supported by a research grant from Sterling Winthrop.

\section{References}

American Fertility Society (1979) Classification of endometriosis. Fert. Steril. 32, 633-634.

Bouckaert, P.X.J.M., Evers, J.L.H., Doesburg, W.H., Schellekens, L.A., Brombacher, P.J. \& Rolland, R. (1986a) Patterns of changes in proteins in the peritoneal fluid of women during the periovulatory phase of the cycle. J. Reprod. Fert. 77, 329-336.

Bouckaert, P.X.J.M., Evers, J.L.H., Doesburg, W.H., Schellekens, L.A. \& Rolland, R. (1986b) Patterns of changes in glycoproteins, polypeptides, and steroids in the peritoneal fluid of women during the periovulatory phase of the cycle. J. clin. Endocr. Metab. 62, 293-299.

Casslén, B. \& Ohlsson, K. (1981) Cyclic variation of proteinase inhibitors in human uterine fluid and influence of an IUD. Contraception 23, 425-434.

DeLeon, F.D., Vijayakumar, R., Brown, M., Rao, Ch.V., Yussman, M.A. \& Schultz, G. (1986) Peritoneal fluid volume, estrogen, progesterone, prostaglandin, and epidermal growth factor concentrations in patients with and without endometriosis. Obstet. Gynecol. 68, 189-194.

Drake, T.S., Metz, S.A., Grunert, G.M. \& O'Brien, W.F. (1980) Peritoneal fluid volume in endometriosis. Fert. Steril. 34, 280-281.

Fazleabas, A.T., Khan-Dawood, F.S. \& Dawood, M.J. (1987) Protein, progesterone, and protease inhibitors in uterine and peritoneal fluids of women with endometriosis. Fert. Steril. 47, 218-224.

Halme, J., Becker, S. \& Haskill, S. (1987) Altered maturation and function of peritoneal macrophages: possible role in pathogenesis of endometriosis. Am. J. Obstet. Gynecol. 156, 783-789.

Haney, A.F., Muscato, J.J. \& Weinberg, J.B. (1981) Peritoneal fluid cell populations in infertility patients. Fert. Steril. 35, 696-698.

Koninckx, P.R., Renaer, M. \& Brosens, I.A. (1980) Origin of peritoneal fluid in women: an ovarian exudation product. Br. J. Obstet. Gynaecol. 87, 177-183.

Künzig, H.J., Schmidt-Rohde, P., Krämer, M. \& Prinz, H. (1985) Akute-Phase-Proteine (C-Reaktives Protein, Orosomucoid, Haptoglobin)- Spezifische Marker bei der Diagnostik entzündlicher Adnexerkrankungen. Geburtsh. Frauenheilk. 45, 881-886.

Kushner, I. (1982) The phenomenon of the acute phase response. Ann. N. Y. Acad. Sci. 389, 39-48.

Maathuis, J.B., Van Look, P.F.A. \& Michie, E.A. (1978) Changes in volume, total protein and ovarian steroid concentrations of peritoneal fluid throughout the human menstrual cycle. J. Endocr. 76, 123-133.

Mancini, G., Carbonara, A.O. \& Heremans, J.F. (1965) Immunochemical quantitation of antigens by single radial immunodiffusion. Immunochemistry $\mathbf{2}$, 235-254.

Nathan, C.F. (1987) Secretory products of macrophages. J. clin. Invest. 79, 319-326.

Pepys, M.B. (1981) C-reactive protein fifty years on. Lancet 1, 653-657.

Syrop, C.H. \& Halme, J. (1987a) Cyclic changes of peritoneal fluid parameters in normal and infertile patients. Obstet. Gynecol. 69, 416418 . 
Syrop, C.H. \& Halme, J. (1987b) Peritoneal fluid environment and infertility. Fert. Steril. 48, 1-9.

Vernon, M.W., Beard, J.S., Graves, K. \& Wilson, E.A. (1986) Classification of endometriotic implants by morphologic appearance and capacity to synthesize prostaglandin F. Fert. Steril. 46, 801-806.
Ylikorkala, O., Koskimies, A., Laatkainen, T., Tenhunen, A. \& Viinikka, L. (1984) Peritoneal fluid prostaglandins in endometriosis, tubal disorders, and unexplained infertility. Obstet. Gynecol. 63, 616-620.

Received 17 November 1987 